\title{
New Concept of Learning Outcomes Assessment in Adaptive Mobile Learning
}

\author{
I Made Agus Wirawan ${ }^{1}$, I Gede Mahendra Darmawiguna ${ }^{2}$ \\ ${ }^{1,2}$ Departement of Informatics Education \\ Universitas Pendidikan Ganesha \\ Singaraja, Indonesia \\ 1imade.aguswirawan@undiksha.ac.id, 2mahendra.darmawiguna@undiksha.ac.id
}

\begin{abstract}
Although technology can positively affect learning process, learning technology like Adaptive Mobile Learning (ALM) for assessment still poses two main problems in terms of its tests session value and the possibility of the test being taken repeatedly by learners. This study proposes the use of Simple Additive weighting method (SAW) to improve AML systems by using tree criteria, such as: test session, learning session number and learning intensity. These criteria to enable the learning process according to their level of competence. A model of AML system is then drafted by applying the SAW Method with the infusion of the tree criteria based on Bloom's Taxonomy. It is strongly recommended that a research in near future 1) should be conducted to develop AML system using SAW method for optimizing the learning assessment on AML system and 2) can add an assessment rubric based on Blooms Taxonomy Model.
\end{abstract}

Keywords-Adaptive Learning; Mobile Learning; Assessment; Simple Additive Weighting; Cognitive; Affectiv; Learning Outcomese.

\section{INTRODUCTION}

Conventionally, the learning process is done face to face between teachers with learners in the classroom. Teachers have a very important role in determining the quantity and quality of the implementation study. Therefore, teachers must think and plan carefully to improve learning opportunities for learners and improve the quality of teaching. Today, technology has become a critical requirement in the learning process, both as a medium of learning or learning resource. It is marked with a number of functions on a mobile device. This became the beginning of the evolution of mobile devices, in this case is characterized by the emergence of smart phone technology. Smartphone technology is a new class of mobile device that can facilitate access and data processing computing power [1]. The rapidly increasing development of mobile technology and communication enables the learning process to be conducted beyond the classrooms during school hours. With mobile technology and communication, teaching and learning process can be conducted anywhere and anytime.

In the learning process, each learner has different cognitive abilities Dzaki [2]. This problem can be overcome by using adaptive learning system. $[3,4,5,6,7]$. According the research conducted by Wirawan and Santo [5] the use of Adaptive Mobile Learning (AML) in Information Systems courses can be prepared in accordance with the ability of students with a pre-test and test session. AML can be used as an alternative media (supplement) in information systems courses. Student responses on the use of AML for information systems are very positive, where $67.7 \%$ are in very positive and $32.3 \%$ are on the positive.

However, AML has two disadvantages. First of all, the assessment process uses only the test session value, while according to Bloom's taxonomy, the assessment of learning outcomes should include three aspects, namely a) Cognitive, b) Psychomotor, c) Affective. Secondly, each learner can perform repeatedly a test session, so that the students who get a score of 90 for several times the test session is considered equal to learners who obtain a score of 90 for just one test session. This will not reflect students' learning outcome fairly for students taking the session once compared to those who take it several times.

These assessment issues can be handled using Simple Additive weighting method (SAW). These problems can be handled using Simple Additive weighting method (SAW) $[8,9,10]$. SAW is a method of artificial intelligence that can be used in the decision-making process based on the determination of the weight values for each attribute and continued with the process of assessment the best alternative selecting from a number of the best alternative [11]. The present study will develop an ALM model with SAW to accommodate the infusion of Bloom's Taxonomy to improve the effectiveness of ALM for assessing learner's learning outcomes.

\section{LITERATURE REVIEW}

The present section will present a review of the literature that deals with the educational aspects that become concerns this research.

\section{A. Multi-Attribute Decision Making (MADM)}

MADM refers to screening, prioritizing, ranking, or selecting a set of alternatives usually under independent, incommensurate or conflicting attributes [11]. A MADM problem can be concisely expressed in the matrix format as shown below:

$$
A=\left\{a_{i} \mid i=1,2,3, \ldots \ldots . ., n\right\}
$$




$$
\begin{aligned}
& \mathrm{C}=\left\{\mathrm{c}_{\mathrm{i}} \mid \mathrm{j}=1,2,3, \ldots \ldots \ldots, \mathrm{m}\right\} \\
& \mathrm{W}=\left\{\mathrm{w}_{1}, \mathrm{w}_{2}, \mathrm{w}_{3} \ldots \ldots . ., \mathrm{w}_{\mathrm{n}}\right\} \\
& X=\left[\begin{array}{ccc}
x_{11} & x_{m 1} \cdots & x_{1 n} \\
\vdots & \ddots & \vdots \\
x_{m 1} & x_{m 2} \cdots & x_{m n}
\end{array}\right]
\end{aligned}
$$

Where $A_{1}, A_{2}, \ldots, A_{n}$ are feasible alternatives, $C_{1}, C_{2}, \ldots, C_{n}$ are attributes (criteria), $x_{i j}$ is the performance rating of $i$-th alternative with respect to $j$ attribute, and $w_{j}$ is a weight (significance) of $\mathrm{j}$ attribute.

In a typical MADM evaluation, attributes can be classified into two main categories: cost attributes and benefit attributes. In the case of benefit attributes, the higher score is assigned to the alternative which performance rating is higher, i.e., preferable is a maximum of $\mathrm{j}$ attribute. In contrast to the previous, in the case of cost attributes, higher score is assigned to the alternative which performance rating is lower, i.e., the minimum of $\mathrm{j}$ attribute is preferable.

There are three approaches to find the value of weight an attribute, namely subjective approach, objective approach and integration approach. Each approach has advantages and disadvantages. On the subjective approach, weighting value is determined based on decision makers, so some of the factors in the process of rank alternative can be determined freely. On the objective approach, value of weight calculated mathematically, so ignore subjective from the decision makers.

\section{B. Simple Additive Weighting Method (SAW)}

The basic concept of SAW method is to find the sum of the weighted performance rating for each alternative on all attributes [11]. SAW method requires a process of normalizing the decision matrix $(\mathrm{X})$ to a scale that can be magnified compared with all the ratings of existing alternatives.

$r_{i j}=\left\{\begin{array}{l}\frac{X_{i j}}{\operatorname{Max}_{i j}} \\ \frac{\operatorname{Min}_{i j}}{X_{i j}}\end{array}\right.$

If $\mathrm{X}_{\mathrm{ij}}$ is an attribute cost

If $\mathrm{X}_{\mathrm{ij}}$ is an attribute benefit

Where $r_{i j}$ is the normalized performance rating of alternative $A_{i}$ on attributes $C_{j} ; \mathrm{i}=1,2, \ldots, \mathrm{m}$ and $\mathrm{j}=1,2, \ldots, \mathrm{n}$. Preference value for each alternative $\left(V_{i}\right)$ is given as:

$$
V_{i}=\sum_{j=1}^{n} w_{j} r_{i j}
$$

$V_{i}$ Larger value indicates that the $A_{i}$ alternative is selected. SAW method also known as scoring method is one of the best and simplest types of multiple attribute decision-making method. The basic logic of the SAW method is to obtain a weighted sum of performance ratings of each alternative over all attributes. The stepwise procedure is given below:
$\mathrm{A}=\left(\mathrm{a}_{1}, \mathrm{a}_{2}, \ldots \ldots \ldots, \mathrm{a}_{\mathrm{n}}\right)$

Let $A=\left(a_{1}, a_{2}, a_{3}, \ldots, a_{n}\right)$ be a set on alternatives.

$$
\mathrm{C}=\left(\mathrm{c}_{1}, \mathrm{c}_{2}, \ldots \ldots \ldots, \mathrm{c}_{\mathrm{n}}\right)
$$

Let $C=\left(c_{1}, c_{2}, c_{3}, \ldots, c n\right)$ be a set of criteria.

1. Step 1: Construct the decision matrix:

$$
\begin{array}{ccc}
d_{11} & d_{12} & d_{1 n} \\
d_{21} & d_{22} & d_{2 n} \\
\ldots & \ldots & \ldots \\
d_{n 1} & d_{n 2} & d_{n n}
\end{array}
$$

Where $d_{i j}$ is the rating of alternative $A_{i}$ with respect to criterion $\mathrm{C}_{\mathrm{i}}$.

2. Step 2: Construct the normalized decision matrix. For beneficial attribute (criteria of benefit):

$$
r_{i j}=\frac{X_{i j}}{\operatorname{Max}_{i j}}
$$

For non-beneficial attribute (criteria of cost):

$$
r_{i j}=\frac{\operatorname{Min}_{i j}}{X_{i i}}
$$

3. Step 3: Construct weigthed normalized decision matrix

$$
V_{i j}=W_{i j} * r_{i j}, \sum_{i=1}^{n} W_{i}=1
$$

4. Step 4: Calculate the score of each alternative.

$$
S_{i}=\sum_{i=1}^{n} V_{i j}, i=1,2,3, \ldots, n \text {. }
$$

5. Step 5: Select the best alternative.

$$
B A_{S A W}=\max \underset{i=1}{n} S_{i}
$$

Where BA saw is Best Alternative in Simple Additive Weighting (SAW) method and $S_{i}$ is matrix score.

\section{Adaptive Mobile Learning}

The functional design of the AML learning in previous research that will be studied in this research can be shown clearly in Figure 1.

There are four stages on the learning process of AML: (1) Perform a pre-test to learners prior to learning chapter (courses), students will receive pre-test with the following provisions. (2) Questions were taken representing each chapter. (3) Teachers determine the questions selected for the pre-test. (4) The results passed or not are determined by the percentage of the number of chapters of the correct answers to the questions in each chapter, where the teacher determines the percentage of pass for each chapter.

The purpose of the pre-test is to determine the ability of early learners. After the pre-test, the system will give a chapter that can be accessed in accordance with the level of understanding of learners. Some possible after pre-tests can be conducted: (1) No chapters pass. If all the chapters are not 
passed, students can only access the lowest chapter that has not been passed. (2) Some or all chapters pass. If there are several chapters that pass, then pass only chapter that can be accessed. If all chapters pass then all the chapters can be accessed.

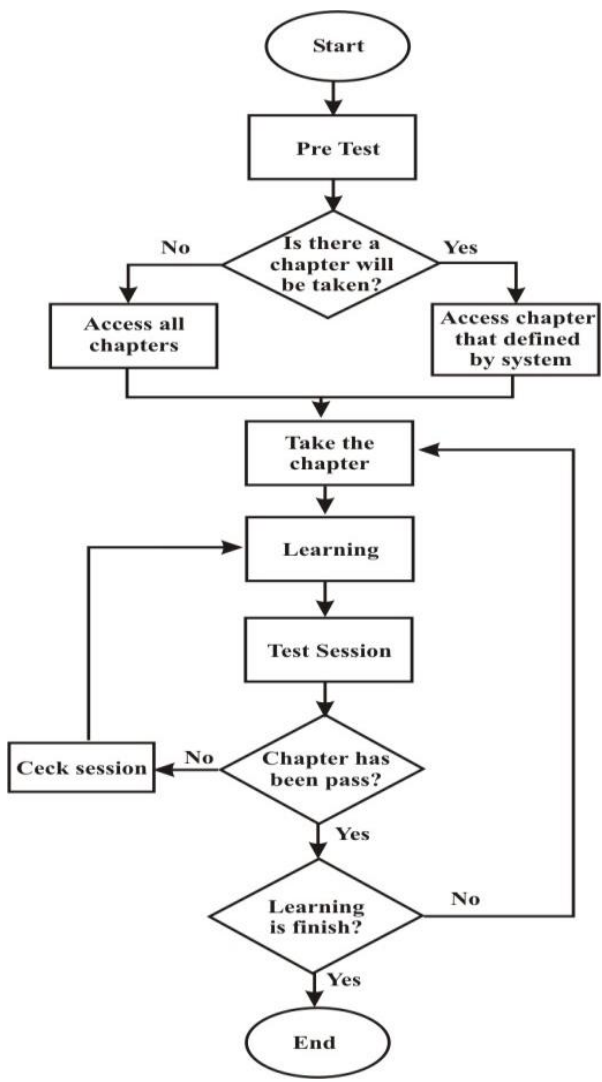

Fig. 1 Flow chart Adaptive Mobile Learning $[5,7]$

For taking a chapter, there are two conditions in taking the matter: (1) The conditions in which the students are free to choose the material. (2) The conditions in which learners must take the matter determined by the system. This happens because there is a chapter that did not pass the pre-test.

After the learning process, students were asked by system to take a test session. All provisions for the provisions of the test session are as follows: (1) Questions are taken from the test session is a chapter that has been taken. (2) Standard passing score is determined set by lecturer. (3) If students do not take the test session, students cannot continue the learning process. (4) The results obtained later by learners are pass or not pass in each chapter.

There are several possibilities in this test session: (1) If students do not pass the test session, students will repeat the learning process for the chapters that did not pass. Repetition of the learning process will be stored by the system as a learning session. (2) If students pass the test session, students can continue to the next chapter to the learning process end. If all the chapters have been completed, students can complete the learning process. In the test session, the value obtained by learners is only used to determine graduation. The learning process for each chapter is based on the minimum standards set by lecturer. However, every learner can perform repeatedly a test session, so that the students who get a score of 90 for several times the test session is considered equal to learners who obtain a score of 90 for just one test session. The pretest user interface developed in AML is shown in Figure 4. Interface pretest is used to measure the initial capabilities of learners. There are several provisions in the pre-test processes such as. (1) The questions are presented is the early material of each chapter. (2) The teacher can determine the number or type of questions selected for the pre-test. (3) The results passed or not are determined by the percentage of the number of chapters of the correct answers to the questions in each chapter, where the teacher determines the percentage of pass for each chapter.

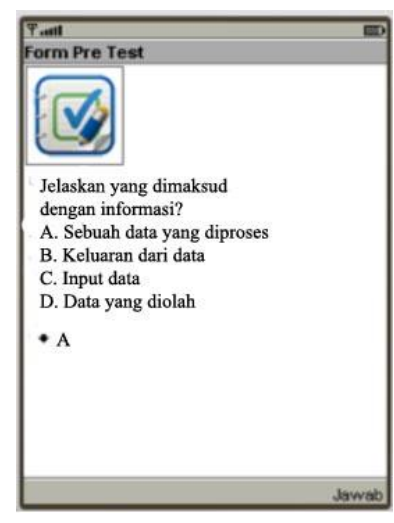

Fig. 2 Pretest form

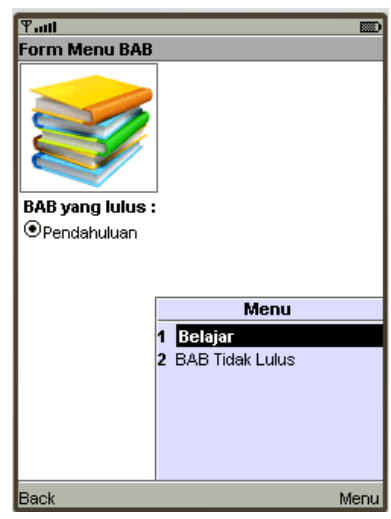

Fig. 3 Chapter form
Figure 2 is used to display the chapter material that passes from the pretest (Figure 3). There are two conditions in the learning process. (1) The learner can access the chapter that has passed freely. (2) Learners can access the chapter that does not pass (pre-test) in accordance with the directives of the system. Figure 4 is used to display the chapter material that not passes from the pretest. If chapter materials are passes, students can freely access the material. While the chapter material that has not yet passed, access to the materials will be determined by the system according to the level of the chapter material. After all the learning process is done by learners, then the next process is test session in Figure 5. 


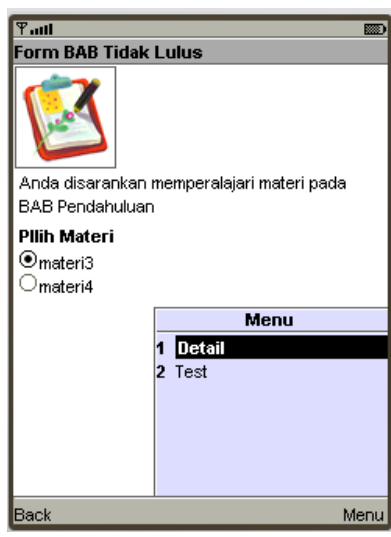

Fig. 4 Content form

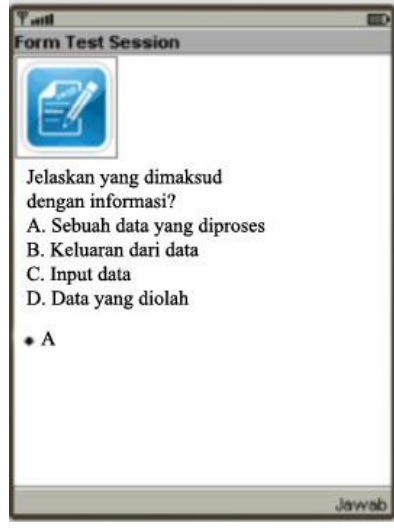

Fig. 5 Test session form

\section{Blooms Taxonomy Model}

In 1950 Benjamin Bloom developed a learning taxonomy, which was then known as a Bloom's taxonomy. Taxonomy itself is defined as a classification device of learner's cognitive process, which is involved in learning objective [12, 13, 14]. Bloom classified learning process into three-psychology domain i.e.: cognitive, affective, and psychomotor. Cognitive aspect is oriented thinking skills that include intellectual ability that is simpler, which remember, to the ability to solve problems that require students to join the new and incorporating some ideas, ideas, methods or procedures studied to solve the problem. Cognitive skill of learners in learning process divides into six different categories namely: knowledge (C1), comprehension (C2), application (C3), analysis (C4), synthesis (C5), and evaluation (C6). Each category is stated using noun word (Fig. 6).

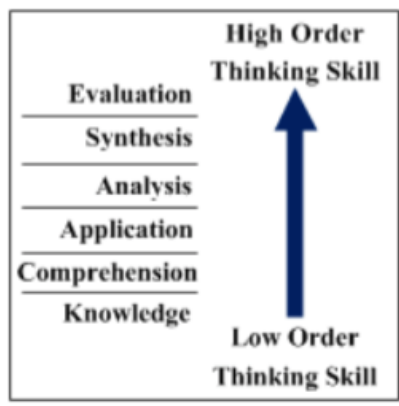

Fig. 6 Blooms Taxonomy Model

Affective domain is associated with the realm of attitudes and values. Affective includes character behaviors such as feelings, interests, attitudes, emotions, and values. Some experts say that a person's attitude can be foreseen amendments when someone has high-level cognitive powers. The characteristics of affective learning outcomes will look at learners in a variety of behaviors.

Psychomotor is the domain-related skills (skills) tau's ability to act after someone receives a specific learning experience. Psychomotor learning outcomes are actually a continuation of the cognitive learning (understanding something) and affective learning outcomes (the new look in the form of tendencies to behave). Results of learning skills (psychomotor) can be measured by: (1) direct observation and assessment of the behavior of learners during practice learning takes place, (2) after the following study, by way of giving tests to students to measure knowledge, skills, and attitudes, (3) sometime after the study was completed and later in the work environment. [15, 16, 17]. There are five important traits that can be used for student affective assessment, namely attitude, interest, self-concept, value, and moral [18].

\section{New CONCEPT For THE Assessment PROCESS USING Additive Weighting ON ADAPTIVE MobiLE LEARNING}

\section{A. New Concept using SAW Method in AML}

In this study, only two of the three taxonomy blooms used, including: cognitive and affective.

1. The cognitive aspects of the learners will be measured through the criteria of the results of the test session and the learning session number.

2. The affective aspect of learners will be measured through the learning intensity.

Based on AML, learning process is conducted in several additional phases ranking process by using SAW method. Following the addition of the steps proposed in this paper looks at the blue rectangular blocks.

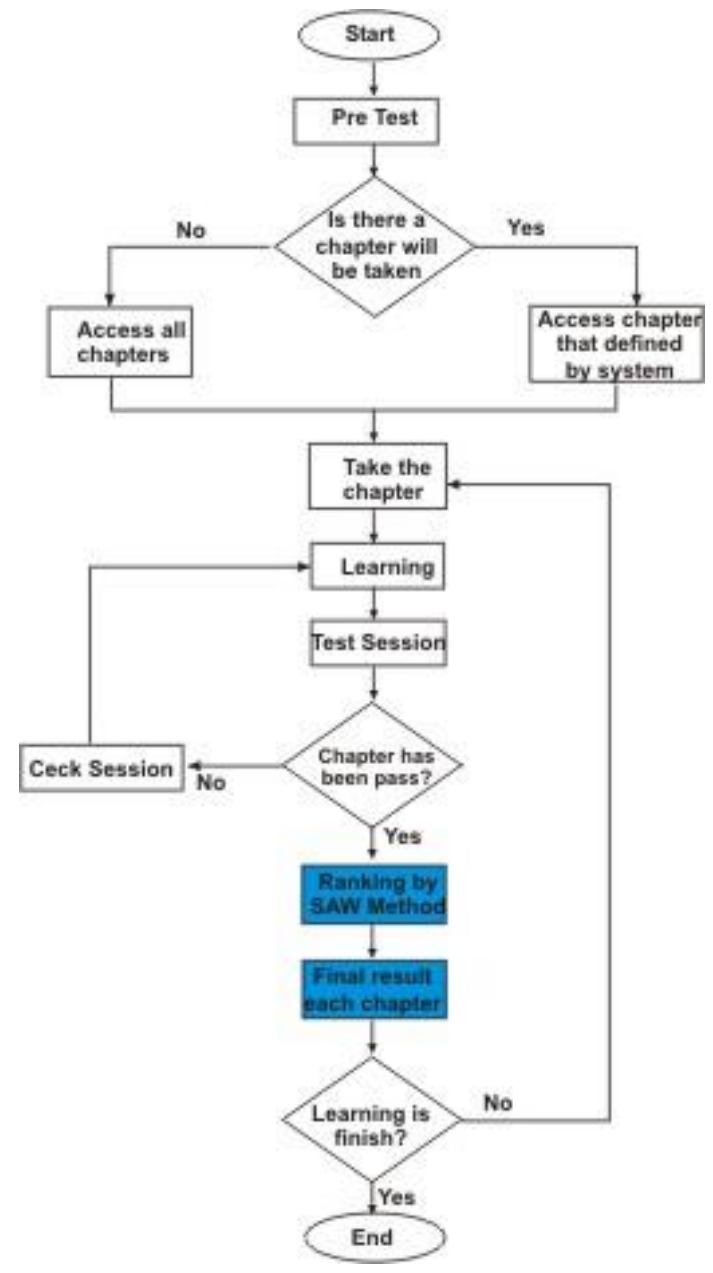

Fig. 7 Modification AML with SAW Method. 


\section{B. Calculation of Assessment using SAW Method}

The SAW method is used to determine the final value of the learner's test and then perform a rating based on the value of the SAW method. The criteria used in determining the rankings are: 1) the value of the test session (benefit criteria), 2) the learning session (cost criteria) and 3) Learning intensity (cost). The value of the test session is obtained from the test of the learner after the learning of each chapter is completed. The standards of these criteria can be tailored from each chapter. The value of the learning session criteria is obtained from learners who repeat the test session. This is because the value of the test session obtained does not meet the standards set by each chapter. The lower of the learning session, then the faster of the learner's level to understand the chapter of the material. However, if the high value of the learning session is low, then the learner will take longer to understand the chapter material. Learning intensity value is derived from the amount of time that the learner uses in learning the material each chapter. The less time spent, the higher the motivation to learn the learners. Vice versa, the lower the motivation to learn learners. Here is an example of the data used in the calculation method in SAW (Simple Additive Weighting). Here are the steps of SAW calculation method:

1. Problem formulation

Suppose there are 10 learners who have test session values, learning session and learning intensity. The following sample data is used.

Table .1 Test scores data of learners

\begin{tabular}{|l|l|l|l|l|}
\hline No & Student & $\begin{array}{c}\text { Test } \\
\text { Session }\end{array}$ & $\begin{array}{c}\text { Learning } \\
\text { Session }\end{array}$ & $\begin{array}{c}\text { Learning } \\
\text { Intensity }\end{array}$ \\
\hline 1. & Student 1 & 80 & 2 & 10 minutes \\
\hline 2. & Student 2 & 78 & 1 & 15 minutes \\
\hline 3. & Student 3 & 98 & 1 & 20 minutes \\
\hline 4. & Student 4 & 84 & 3 & 35 minutes \\
\hline 5. & Student 5 & 79 & 2 & 45 minutes \\
\hline 6. & Student 6 & 99 & 3 & 50 minutes \\
\hline 7. & Student 7 & 97 & 1 & 25 minutes \\
\hline 8. & Student 8 & 76 & 2 & 40 minutes \\
\hline 9. & Student 9 & 75 & 3 & 30 minutes \\
\hline 10. & Student 10 & 88 & 2 & 10 minutes \\
\hline
\end{tabular}

2. Determining the weight value preferences

In granting the weights, lecturers of the course can decide for themselves the value of the weight of each criterion. In this example, use the weight 1 for the learning session, the test session is 10 and the learning intensity is 1 .

3. Determining the maximum value for limit alternative. At this stage, the determination of the limit values (maximum or minimum) of the test session value, learning session and learning intensity. Value of 100 for the test session, 1 for the learning session and minimum values from all learning intensity of learners.

4. Make a decision matrix (X) formed from the rating table matches on each criterion.
Table.2 Alternative format

\begin{tabular}{|c|c|c|c|}
\hline Code & $\begin{array}{c}\text { Test } \\
\text { Session } \\
\text { (Max) }\end{array}$ & $\begin{array}{c}\text { Learning } \\
\text { Session } \\
\text { (Min) }\end{array}$ & $\begin{array}{c}\text { Learning } \\
\text { Intensity } \\
\text { (Min) }\end{array}$ \\
\hline A1 & 80 & 2 & 10 \\
\hline A2 & 78 & 1 & 15 \\
\hline A3 & 98 & 1 & 20 \\
\hline A4 & 84 & 3 & 35 \\
\hline A5 & 79 & 2 & 45 \\
\hline A6 & 99 & 3 & 50 \\
\hline A7 & 97 & 1 & 25 \\
\hline A8 & 76 & 2 & 40 \\
\hline A9 & 75 & 3 & 30 \\
\hline A10 & 88 & 2 & 10 \\
\hline Max & $\mathbf{1 0 0}$ & $\mathbf{1}$ & $\mathbf{1 0}$ \\
\hline
\end{tabular}

5. Make a decision matrix (X) and Normalizing the decision matrix with alternative normalization $\mathrm{Ai}$ on performance $\mathrm{C} \mathrm{j}$.

6. The final result of the preference value (Vi) obtained from the sum of the rows of the matrix multiplication result element normalized (R) with a weight of preferences $(\mathrm{W})$.
1. $\mathrm{V} 1=(0,800)(10)+(0,500)(1)+(1,00)(1)=9,50$
2. $\mathrm{V} 2=(0,780)(10)+(1,000)(1)+(0.67)(1)=9,47$
3. $\mathrm{V} 3=(0,980)(10)+(1,000)(1)+(0.5)(1)=11,30$
4. $\mathrm{V} 4=(0,840)(10)+(0,333)(1)+(0.286)(1)=9.02$
5. $\mathrm{V} 5=(0,790)(10)+(0,500)(1)+(0.22)(1)=8,62$
6. $\mathrm{V} 6=(0,990)(10)+(0,333)(1)+(0.2)(1)=10,43$
7. $\mathrm{V} 7=(0,970)(10)+(1,000)(1)+(0.4)(1)=11,10$
8. $\quad \mathrm{V} 8=(0,760)(10)+(0,500)(1)+(0.25)(1)=8,35$
9. $\mathrm{V} 9=(0,750)(10)+(0,333)(1)+(0.33)(1)=8,13$
10. $\mathrm{V} 10=(0,880)(10)+(0,500)(1)+(1)(1)=10,30$
11. $M a x=(1)(10)+(1)(1)+(1)(1)=12$

12. The final result of the preference value $(\mathrm{Vi})$ be normalized value by value (Vi) multiplied by 100 and divided by the value of the number of alternative value (Max) then get the results (Vi) which is new.
1. $\mathrm{V} 1=(9,50 * 100) / 12=79,167$
2. $\mathrm{V} 2=(9,47 * 100) / 12=78,91$
3. $\mathrm{V} 3=(11,30 * 100) / 12=94,167$
4. $\mathrm{V} 4=(9,02 * 100) / 12=75,167$
5. $\mathrm{V} 5=(8,62 * 100) / 12=71,83$
6. $\mathrm{V} 6=\left(10,43^{*} 100\right) / 12=86,9167$
7. $\mathrm{V} 7=(11,10 * 100) / 12=92,5$
8. $\mathrm{V} 8=(8,35 * 100) / 12=69,583$
9. $\mathrm{V} 9=(8,13 * 100) / 12=67,75$
10. $\mathrm{V} 10=(10,30 * 100) / 11=85,83$
11. $\operatorname{Max}=(12 * 100) / 12=100$

13. The results of the calculation of the value of $\mathrm{Vi}$ is then obtained students' final grades. 
Table.3 New score using SAW Method

\begin{tabular}{|l|l|c|c|}
\hline No & \multicolumn{1}{|c|}{ Student } & Score & $\begin{array}{c}\text { New Score (SAW } \\
\text { Method) }\end{array}$ \\
\hline 1. & Student 1 & 80 & 79,167 \\
\hline 2. & Student 2 & 78 & 78,91 \\
\hline 3. & Student 3 & 98 & 94,167 \\
\hline 4. & Student 4 & 84 & 75,167 \\
\hline 5. & Student 5 & 79 & 71,83 \\
\hline 6. & Student 6 & 99 & 86,9167 \\
\hline 7. & Student 7 & 97 & 92,5 \\
\hline 8. & Student 8 & 76 & 69,583 \\
\hline 9. & Student 9 & 75 & 67,75 \\
\hline 10. & Student 10 & 88 & 85,83 \\
\hline
\end{tabular}

\section{CONCLUSION AND SUGGESTION}

There are two significant results in this study. First, the present study contributes to the concepts in the assessment of learning outcomes in AML Systems using SAW method. The criteria of learning sessions, learning intensity and test sessions value can be used in determining the final grade. Criteria learning sessions are cost criteria that can effect of the final value. The more number of time the students take to repeat the learning sessions will affect the value of the test session. Secondly, the study also has drafted AML Systems using SAW method. Further research can be conducted 1) to improve the proposed AML system development using SAW method for optimizing the learning assessment on AML system. 2) can add an assessment rubric based on Blooms Taxonomy Model.

\section{REFERENCES}

[1]. Yau, J. Y. K., \& Joy, M. (2010). Proposal of a mobile learning preferences model. International Journal of Interactive Mobile Technologies (iJIM), 4(4), 49-51.

[2]. Hernawati, K. 2011. E-Learning Adaptif Berbasis Karakteristik Peserta Didik, Prosiding Seminar Nasional Penelitian, Pendidikan dan Penerapan MIPA, Fakultas MIPA. Universitas Negeri Yogyakarta. 14 Mei 2011. ISBN: 978-979-99314-5-0

[3]. Sfenrianto. 2009. A Model Of Adaptive E-Learning System Based On Student's Motivation, Proceedings International Conference on
Creative Communication and Inovative Technology (ICCIT). 8 Agustus 2009. Tanggerang-Indonesia. ISSN 1978-8282

[4]. Surjono, H.D. 2013. Pemanfaatan Teknologi E-Learning Adaptif untuk Mengatasi Keragaman Gaya Belajar. Jurnal Penelitian Saintek, Vol 8. No

[5]. Wirawan, I. M.A \& Gitakarna, M. S. 2015, Development of Adaptive Mobile Learning (AML) on Information System Courses, International Journal of Advanced Computer Science and Applications(IJACSA), 6(12)

[6]. Dantes, G. R. Suarni, N. K, \& Sujaya, I. G. 2010. Model Dynamic Intellectual Learning (DIL): Pergeseran Paradigma E-Learning Menuju Adaptive Learning, Konferensi Nasional Sistem dan Informatika. Bali, November 13. 2010;

[7]. Wirawan, I. M. A \& Wahyuni, D. S. 2014. Adaptive Mobile Learning Concept, Proceedings of the International Mobile Learning Festival. June 2 - 4. 2014. Bali - Indonesia

[8]. Azizzadeh, F. Alireza Shirvani, A \& Sfestani, S. 2014. Ranking Motivational Factors of Teachers in Urmia Using SAW Method. International Journal of Managing Value and Supply Chains (IJMVSC). Vol.5. No. 1, March 2014

[9]. Widayanti, D. Sudana, O \& Sasmita, A. 2013. Analysis and Implementation Fuzzy Multi-Attribute Decision Making SAW Method for Selection of High Achieving Students in Faculty Level, International Journal of Computer Science Issues. Vol. 10. Issue 1. No 2. January 2013 ISSN (Print): 1694-0784 | ISSN (Online): $1694-$ 0814;

[10]. Afshari, A. Mojahed, M \& Yusuff, R.M. 2010. Simple Additive Weighting approach to Personnel Selection problem, International Journal of Innovation, Management and Technology. Vol. 1. No. 5. December 2010 ISSN: 2010-0248

[11]. Kusumadewi, S. 2006. Fuzzy Multi- Attribute Decision Making (Fuzzy MADM). Yogyakarta: Graha Ilmu.

[12]. I Nyoman Sukajaya ${ }^{1,2}$, I Ketut Eddy Purnama ${ }^{1}$ and Mauridhi Hery Purnomo 1

[13]. M. Minovi!, M. Milovanovi!, U. "o\#evi!, and M. Á. Conde González, "Visualisation of student learning model in serious games," Comput. Hum. Behav.

[14]. T. Highley and A. E. Edlin, "Discrete Mathematics assessment using learning objectives based on Bloom's taxonomy," in 39th IEEE Frontiers in Education Conference, 2009. FIE '09, 2009, pp.1-6.

[15]. Anderson, L.W., \& Krathwohl, D.R. (eds.). (2001). A taxonomy for learning, teaching and assessing: A revision of Bloom's Taxonomy of educational objectives. New York: Longman.

[16]. Dave, R.H. (1975). Developing and writing behavioral objectives. ( $\mathrm{R}$ J Armstrong, ed.) Educational Innovators Press.

[17]. Krathwohl, D.R., Bloom, B.S., \& Masia, B.B. (1964). Taxonomy of educational objectives: The classification of educational goals. Handbook II: Affective domain. New York: David McKay Co

[18]. Andersen, Lorin. W. (1981). Assessing affective characteristic in the schools. Boston: Allyn and Bacon. 